\title{
Pierwsza wojna światowa a powstanie Republiki Czechosłowackiej (Czesko-Słowackiej) 1914-1920 (Zagadnienia wybrane)
}

Wydarzenia związane z utworzeniem Pierwszej Republiki Czechosłowackiej (Czesko-Słowackiej) rozegrały się w latach 1914-1918. Sarajewski zamach ${ }^{1}$ na

${ }^{1}$ Do ścisłej grupy zamachowców weszli: Danilo Ilić, Nedeljko Čabrinović, Gavrilo Princip, Muhamed Mehmedbašić, Trifko Grabež, Vasa Čubrilović, Cvetko Popović i inni. Na powóz pierwszy rzucił bombę Nedeljko Čabrinović. Para na razie ocalała, ale w chwilę później została śmiertelnie ugodzona kulami z pistoletu, które oddał Gavrilo Princip. (W. Felczak, T. Wasilewski: Historia Jugostawii. Wrocław-Warszawa-Kraków—Gdańsk—Łódź 1985, s. 415).

Prowadzone śledztwo wykazało, że Princip, Grabež i Čabrinović kupowali — przed zamachem — broń w Belgradzie (ibidem, s. 416).

„Dňa 28. júna $1914 \ldots$ podnikli srbskí extrémisti v Sarajeve dva pokusy o atentát na manželský pár Františka Ferdinanda a jeho manželku Žofiu. Prvý pokus o atentát bol neúspešný, druhý, vedený študentom Gavrilom Principom, sa však podaril. Následník trónu ani jeho manželka atentát neprežili”. (R. Letz: Slovenské dejiny. IV: 1914-1938. Bratislava 2010, s. 16).

Szczegółowy opis zamachu przedstawił J. Pajewski: „Gdy para arcyksiążęca wraz ze świtą jechała do ratusza, w kolumnie samochodów pośród licznie zgromadzonej na ulicach publiczności, czeladnik drukarski Čabrinović rzucił bombę. Ale arcyksiążę zdołał odrzucić ją ręką, tak że eksplodowała na jezdni, odłamek ranił adiutanta. Po uroczystości powitalnej w ratuszu następca tronu wyraził chęć odwiedzenia w szpitalu rannego oficera - ofiary zamachu. Podczas jazdy z ratusza do szpitala uczeń Gavrilo Princip oddał do pary arcyksiążęcej dwa strzały śmiertelne. Franciszek Ferdynand i księżna Hohenberg zmarli w kilka czy kilkanaście minut po zamachu”. (J. Pajewski: Pierwsza wojna światowa 1914-1918. Warszawa 1991, s. 40).

Krótkie wzmianki o zamachu zamieścił też: Lexikón slovenských dejín. Red. L. Ada mcíková. Bratislava 1997, s. 124; Lexikón svetových dejín. Red. Y. Kašta nová. Bratislava 1997, s. 115. 
arcyksięcia i następcę tronu Franciszka Ferdynanda i jego żonę księżnę Zofię Hohberg (28 czerwca 1914 r.) był dla Austrii i Węgier pretekstem do wypowiedzenia wojny Serbii (28 lipca 1914 r.). Tak rozpoczęła się pierwsza wojna światowa.

Rok 1918 oznaczał utworzenie państwa czesko-słowackiego. Przyjąć jednak można, że budowę nowego państwa finalizowało (przynajmniej w sensie prawno-państwowym) uchwalenie — 29 lutego 1920 r. konstytucji (czes. i słow. ústava) i ustawy nr 126/20 Zb. o zriadení župných a okresných úradov v Republike Československej. Ramy czasowe niniejszego przyczynku to rok 1914 (terminus a quo) i rok 1920 (terminus ad quem).

I Republika Czechosłowacka (Czesko-Słowacka; 1918-1938) była państwem nowym. Jej obszar (140,446 km² ) tworzyło dawne Królestwo Czech (Böhmen), margrabstwo Moraw (Mähren), kraj koronny Śląsk (Kronland Schlesien), należące do czasu rozpadu Austrii do Cesarstwa Austriackiego (die im Reichsrat vertretenen Königreiche und Länder; Österreichische Kaiserthum); Słowacja (Tóthország, Felvidék), od X w. będąca częścią korony świętego Stefana (węg. Szent István Koronája), tj. Królestwa Węgier (Magyar Királyság, Zalitavia); Podkarpacka Ruś (Ukraina Zakarpacka, Verchovyna), należąca do czasu rozpadu Węgier do Zalitawii, włączona do Republiki na podstawie traktatu pokojowego z Węgrami, zawartego w Trianon 4 czerwca 1920 r.; wreszcie mały skrawek Niemiec, a zarazem Górnego Śląska (czes. Horní Slezsko; słow. Horné Sliezsko; niem. Oberschlesien; łac. Silesia Superior), tj. Okręg Hulczyński (Hlučínsko, Hlutschiner Gau), włączony do Republiki na podstawie traktatu wersalskiego.

II Rzeczpospolita nie była państwem nowym, mimo że od końca I Rzeczypospolitej (1795) do roku 1918 dzieliły ją 123 lata państwowego niebytu; uznana została za Polskę Odrodzoną (Polonia Restituta). Taką nazwę uzasadniała starorzymska konstrukcja iuris postliminii ${ }^{2}$.

Generalnie rzecz biorąc, odbudowa II Rzeczypospolitej była - w czasie, kiedy liczyły się bardziej narody historyczne niż niehistoryczne, to znaczy państwa niemające w przeszłości własnego państwa - łatwiejsza i prostsza niż wspólnego państwa Czechów i Słowaków.

Trójprzymierze (słow. Trojspolok) było sojuszem polityczno-wojskowym, zawartym w 1882 r., obejmującym Niemcy, Austrię, Węgry i Włochy (do roku 1915), stanowiącym przeciwwagę Trójporozumienia (ententa; słow. dohoda), a więc sojuszu polityczno-wojskowego Francji, Rosji i Wielkiej Brytanii, tworzonego w latach 1893, 1904 i 1907.

Stan polityczno-prawny pokonanych państw Trójprzymierza określały traktaty pokojowe: z Niemcami (traktat wersalski, z 28 czerwca 1919 r.) z Austrią

${ }^{2}$ Istotę Iuris postliminii przedstawili m.in.: K. Rebro (Latinské právnické výrazy a výroky. Vybral, preložil a výkladom doplnil K. Rebro. Bratislava 1984, s. 148); W. Wołodkiewicz (Prawo rzymskie. Stownik encyklopedyczny. Red. W. Wołodkiewicz. Warszawa 1986, s. 121); J. Sondel (Stownik łacińsko-polski dla prawników i historyków. Kraków 2005, s. 546, 765); W. Litewski (Stownik encyklopedyczny prawa rzymskiego. Kraków 1998, s. 205). 
(traktat z Saint Germain en Laye z 10 września 1919 r.); i z Węgrami (traktat z Trianon z 4 czerwca 1920 r.).

Pierwsza Republika Czesko-Słowacka (1918-1938) powstała niemal w całości ${ }^{3}$ z ziem Austro-Węgier. Rzeczownik Austro-Węgry sugeruje, że było to państwo unitarne. Tymczasem ugoda austro-węgierska (niem. Vergleich; słow. vyrovnanie) zawarta 4 lutego 1867 r., tworzyła drugie odrębne i niezależne państwo, tj. państwo węgierskie (Magyar Királyság, Zalitavia, słow. Uhorsko; czes. Uhersko; chorw. Ugarska) ${ }^{4}$. Tej odrębności nie niweczyła ani unia personalna, ani - w zakresie trzech dziedzin - unia realna.

O tym, że były to dwa odrębne państwa przesądza osiem faktów 5 .

\section{Quaestio: Cum Austria et Hungaria; aut Extra Austriam et Hungariam}

Na sformułowane wyżej pytanie udzielili — pośredniej czy bezpośredniej odpowiedzi członkowie Czechosłowackiej Rady Narodowej w Paryżu (Eduard Beneš, Tomáš Garrigue Masaryk, Milan Rastislav Štefánik); działacze słowackiego i czeskiego wychodźstwa w USA; posłowie parlamentu wiedeńskiego (Reichsrat) i budapeszteńskiego (Országgyülés); sygnatariusze Umowy Clevelandzkiej i Pittsburskiej; cesarz Karol I; premierzy rządu węgierskiego István Tisza i Mihály Károlyi; minister spraw zagranicznych Austro-Węgier Gyula Andrássy; prezes Słowackiej Partii Ludowej (Slovenská l'udová strana), ksiądz Andrej Hlinka; prezydent Stanów Zjednoczonych Ameryki Woodrow Wilson; konstytucyjne organy państw Ententy uznające Republikę Czesko-Słowacką de facto czy de iure.

${ }^{3}$ Jedynym fragmentem Republiki spoza obszaru Austro-Węgier był mały okręg Hulczyński (Hlučínsko; niem. Hlutsiner Gau), należący do Niemiec, włączony do Republiki postanowieniami traktatu wersalskiego.

${ }^{4}$ „Rakúska monarchia sa pretvorila na dva samostatné štátne útvary... ktoré boli spojené iba spoločným panovníkom a troma ministerstvami (zahraničných vecí, vojny, financií)". (M.S. Ďurica: Dejiny Slovenska a Slovákov v časovej následnosti faktov dvoch tisícročí. Bratislava 2007, s. 223-224).

${ }^{5}$ Istnienie dwóch konstytucji: austriackiej (z 21 grudnia 1867 r.) i węgierskiej z 1848 r., zwanej marcową (márciusi) czy bratysławską (pozsonyi); istnienie dwóch parlamentów: austriackiego (Reichsrat w Wiedniu) i węgierskiego (Országgyülés w Budapeszcie); istnienie dwóch systemów prawa sądowego (np. w Austrii kodeks karny z 1852 r.; na Węgrzech kodeks karny Károlya Csemegi z 1878 r.) i administracyjnego; istnienie dwóch podziałów administracyjno-terytorialnych (w Austrii 17 Kronländer; na Węgrzech: 63 żupy (megye, komitaty węgierskie) i 8 żup chorwacko-slavońskich); istnienie dwóch sądów najwyższych (austriackiego w Wiedniu; i węgierskiego w Budapeszcie); dwa traktaty pokojowe: z Austrią (10 września 1919 r. w Saint Germain en Laye); i z Węgrami (4 czerwca 1920 r. w Trianon); odrębne przystępowanie do otwartych konwencji międzynarodowych (np. do konwencji brukselskiej, z 1903 r., o produkcji i handlu cukrem); istnienie międzynarodowego sporu terytorialnego między $\mathrm{Au}-$ strią i Węgrami o Morskie Oko i Dolinę Rybiego Potoku, zakończonego we wrześniu 1902 r. wyrokiem sądu w stolicy Styrii. 
Te dwa, przeciwstawne, stanowiska przedłożymy w poniższym wykazie źródeł (zdarzeń, faktów, wypowiedzi, publikacji) w układzie chronologicznym. Stanowisko pierwsze, zakładające zachowanie Austrii i Węgier, zawierało wizję przekształcenia tych organizmów politycznych w federację państw narodowych, a stanowisko drugie, zawierające rozbicie Austrii i Węgier, otwierało drogę idei wspólnego państwa Czechów i Słowaków, i jego ustroju (federacja; autonomia Słowacji i Czech; państwo centralistyczne).

Ideę przekształcenia Austrii w federację państw narodowych zapowiadał, wydany 16 października 1918 r., manifest cesarza Karola I: „16 października 1918 roku cesarz Karol I wydał manifest, który miał na celu ratowanie monarchii przez nadanie jej ustroju federacyjnego. Nie mogło to już zahamować postępującego lawinowo rozkładu Austro-Węgier. 11 listopada 1918 roku cesarz Karol zrzekł się »wszelkiego udziału we władzy państwowej «"6.

Austria miała - w ideologii prawno-państwowej - charakter państwa wyjątkowego. Tę wyjątkowość wyrażało hasło Extra Austriam non est vita, a potem ideologia austroslawizmu Franciszka Palackiego, przedstawiona na kongresie słowiańskim w Pradze, w czerwcu 1848 r. Austria była dla Słowian w Austrii tak istotna, że — według Palackiego — gdyby jej nie było, to należałoby ją stworzyć7. „Austrię poczytywano ogólnie za przeciwwagę Niemiec i za niezbędny związek małych narodów i odłamków narodów, za ochronę przed bałkanizacją. Ogólne uznanie znajdowały u Sprzymierzonych słowa Palackiego, że gdyby Austria nie istniała, należałoby ją utworzyć"

Stanowisko kierownictwa Czechosłowackiej Rady Narodowej nie było stabilne i jednolite. Eduard Beneš był w 1908 r. zwolennikiem zachowania Austrii z powodu korzyści gospodarczych, jakie wynikają dla krajów czeskich, należących do rozległego austriackiego rynku gospodarczego. W pracy doktorskiej Le problème autrichien et la question tchèque. Etude sur les luttes politiques des nationalités slaves en Autriche (Paris 1908, obronionej w uniwersytecie w Dijon, socjolog czeski pisał: „Mówi się często o rozpadzie Austrii. Nie wierzę w to absolutnie. Zbyt potężne są więzi historyczne i ekonomiczne, które łączą narody Austrii, aby rozpad ten mógł nastąpić"9.

${ }^{6}$ S. Grodziski: „Habsburgergesetz” - austriacka ustawa konstytucyjna z 3 kwietnia 1919 roku. W: Państwo, prawo, spoleczeństwo w dziejach Europy Środkowej. Księga jubileuszowa dedykowana Profesorowi Józefowi Ciagwie w siedemdziesięciolecie urodzin. Red. A. Lityński, M. Mikołajczyk, T. Adamczyk, A. Drogoń, W. Organiściak. Katowice-Kraków 2009, s. 232.

${ }^{7}$,Jest pewne, że gdyby państwo austriackie już od dawien dawna nie istniało, powinni byśmy w interesie Europy, a nawet ludzkości, natychmiast postarać się o jego stworzenie". (H. Wereszycki: Pod bertem Habsburgów. Zagadnienia narodowościowe. Kraków 1975, s. 115).

8 J. Pajewski: Pierwsza wojna..., s. 728.

${ }^{9}$ Ibidem, s. 720. Według H. Wereszyckiego, w książce E. Beneš ,głosił ideę austroslawizmu". (H. Wereszycki: Pod bertem..., s. 237). 
„Burżuazja czeska [...] upatrywała w związku państwowym z Austrią poważnych korzyści gospodarczych. Taki właśnie pogląd głosił E. Beneš w roku 1908, a więc na 10 lat przed rozpadem monarchii habsburskiej. Twierdził, że w Austrii Czesi mogą czerpać zyski z przynależności do wielkiego mocarstwa"10.

W rzeczywistości więzi historyczne i ekonomiczne nie uchroniły Austrii przed rozpadem, spowodowanym między innymi nierozwiązaną kwestią narodowościową.

Zapewne konfrontacja tezy Beneša z praktyką spowodowała, że ,autor, gdy został ministrem Czechosłowacji, wykupywał, gdzie mógł, i niszczył egzemplarze książki"" rzucając hasło Détruisez l' Autriche - Hongrie! (,Zniszcie Austro-Węgry!”)"2.

Zmieniały się też poglądy T.G. Masaryka. W roku 1913, jako poseł Rady Państwa (Reichsrat), bronił integralności Austrii: „Właśnie dlatego, że nie mogę się oddać marzeniom o rozpadzie Austrii, ponieważ wiem, że ta Austria, czy dobra, czy zła, będzie trwała, poważnie zależy mi na tym, aby z tej Austrii coś zrobić [...]. Nasze prawno-państwowe i administracyjne dążenia nie idą w tym kierunku, aby innych osłabić, ale aby całość wzmacniać"13.

T.G. Masaryk „zajął po wybuchu wojny stanowisko antyaustriackie"14. Taką postawę zaprezentował w mowie, wygłoszonej 6 lipca 1915 r. w Genewie, przedstawiając program zniszczenia monarchii austro-węgierskiej ${ }^{15}$. Od koncepcji proaustriackiej Masaryk odciął się zdecydowanie także w styczniu 1917 r. w artykule Austria est delenda („Należy zniszczyć Austrię”), opublikowanym w Piotrogrodzie w czasopiśmie „Russkaja Volja”, będącym organem carskiego ministra spraw wewnętrznych A.D. Protopopowa. Masaryk pisał w nim między innymi: „Forma samostatného Českého království může býti různa. Dynastie ruského původu byla by nanejvýš populární"16.

Jedynie wiceprzewodniczący Czechosłowackiej Rady Narodowej (słow. Československá národná rada; czes. Československá národní rada) M.R. Štefánik, Słowak z Košarísk, wybitny astronom, francuski generał brygady, nigdy nie bronił istnienia Austrii. Wręcz przeciwnie: organizował we Włoszech, walczące $\mathrm{z}$ armią austro-węgierską, czechosłowackie legiony. Nadto sam dokonywał lotów zwiadowczych nad linią frontu ${ }^{17}$.

10 J. Pajewski: Historia powszechna 1871-1918. Warszawa 1994, s. 58.

11 J. Pajewski: Pierwsza wojna..., s. 732, przypis nr 1.

${ }_{12}$ H. Wereszycki: Pod bertem..., s. 266.

13 Ibidem, s. 237.

${ }^{14}$ J. Pajewski: Pierwsza wojna..., s. 734.

${ }^{15}$ H. Wereszycki: Pod bertem..., s. 263.

16 M.S. Ďurica: Dejiny Slovenska..., s. $280-281$.

${ }^{17}$ Ibidem, s. 283; P. Švorc: Rozbíjali monarchiu. (Populárny slovník osobností česko-slovenského odboja 1914-1918). Košice 1992, s. 117, 121. 
Inaczej wyglądała sytuacja w kraju, tj. na ziemiach czeskich (Czechy, Morawy, Śląsk), gdzie politycy czescy stali długo, w każdym razie oficjalnie, na stanowisku państwowości austriackiej, składając jeszcze w styczniu 1917 r. — na ręce ministrów spraw zagranicznych - deklaracje lojalności ${ }^{18}$.

Po wybuchu pierwszej wojny światowej czechosłowacka partia socjaldemokratyczna (Československá sociálnodemokratická strana) zawiesiła swoją działalność, a jej polityka była zdecydowanie proaustriacka. Podobnie było na Słowacji, gdzie wobec wprowadzenia przez rząd dyktatury wojskowo-biurokratycznej Słowacka Partia Narodowa (Slovenská národná strana) wyraziła w „Gazecie Narodowej” („Národné Noviny”) potrzebę zachowania Węgier, jak i wierność rządowi i dynastii. Tak Słowacka Partia Narodowa i słowacka socjaldemokracja zadeklarowała w „Gazecie Robotniczej” („Robotnícke Noviny”) z 30 lipca 1914 r. zawieszenie działalności i politykę bierności (politika pasivity). Taka postawa miała chronić przed represjami za każdy przejaw słowackości, sympatii wobec Serbii czy wyrażanie nastrojów pacyfistycznych. W tym czasie wrogiem był każdy, kto był przeciwko wojnie, gdyż hasłem rządu uherskiego był - użyty w trybie rozkazującym - czasownik: Éljen a háborút! (Niech żyje wojna!). Mimo to w październiku 1914 r. w więzieniach znalazło się 600 Słowaków ${ }^{19}$. Rząd austriacki nie oszczędził też polityków czeskich ${ }^{20}$.

6 sierpnia 1914 r. prezydium Słowackiej Partii Narodowej opublikowało w „Gazecie Narodowej” („Národné Noviny”) oficjalną deklarację wierności dynastii habsburskiej z obietnicą ponoszenia nawet najcięższych ofiar w jej interesie ${ }^{21}$.

17 sierpnia 1914 r. mieszkający w Warszawie Słowacy opublikowali w polskim czasopiśmie „Echo Słowiańskie” obwieszczenie Preč s Rakúsko Uhorskom! Nech žijú slobodné Česko a Slovensko!22.

Marcowy numer paryskiego czasopisma „Ĺ Indpéndance Tcheque” przyniósł Poslanie na Slovensko, w którym czytamy: „V bratskej zhode, rojčiac za úplnú samosprávu Slovenskej krajiny s vlástnym snemom slovenským v staroslávnej Nitre Tvojej, národ český chce vybudovat's Tebou, národe slovenský, neodvislé súštátie česko slovenské"23.

„Slovenská liga v Amerike vyhlásila zbierku na akciu za osamostatnenie Slovenska, prípadne vymáhanie samosprávy pre slovenský národ"24. W komentarzu do akcji, zamieszczonym 2 czerwca 1915 r. w organie Słowackiej Ligi

18 J. Pajewski: Pierwsza wojna..., s. 735, 738.

${ }_{19}$ L. Hubenák: Právne dejiny Slovenska do roku 1945. II diel. Banská Bystrica [b.r.w.], s. 100; R. Letz: Slovenské dejiny..., s. 18.

${ }^{20}$ „Przez cały czas wojny około 5000 ludzi przeszło przez więzienia austriackie”. (H. Wereszycki: Pod bertem..., s. 265).

${ }^{21}$ M.S. Ďurica: Dejiny Slovenska..., s. 274.

22 Ibidem, s. 275.

${ }^{23}$ Ibidem, s. 277.

${ }^{24}$ Ibidem, s. 278. 
„Jednota”, Matúš Jankola pisał: „Nikomu na svete nechceme byt' poddaní teda ani Mad'arovi, ani Nemcovi, ani Rusovi, ani Poliakovi, ani Čechovi. Slováci ako slobodný národ patria medzi slobodné národy. Nadvládu, nadpanstvo ani mad’arské, ani nemecké, ani ruské, ani české nechceme nad sebou"25.

Utworzenie wspólnego państwa Czechów i Słowaków, poza Austrią i Węgrami, przewidywała Umowa Clevelandzka (23 października 1915 r.) i Umowa Pittsburska (30 maja 1918 r.).

Za powstaniem wspólnego państwa Czechów i Słowaków, s úplným samourčovacím právom slovenského národa opowiadał się w styczniu 1918 r. przewodniczący Słowackiej Partii Ludowej, Andrej Hlinka. 24 maja 1918 r., w czasie tajnej narady Słowackiej Partii Narodowej (Slovenská národná strana) powtórzył swoje stanowisko w sprawie budowy wspólnego państwa, poza państwem węgierskim: „Tisícročné manželstvo s Mad’armi sa nevydarilo. Musíme sa rozíst”26.

Za zachowaniem Austro-Węgier i za przyznaniem autonomii zamieszkującym je narodom opowiadał się prezydent Stanów Zjednoczonych Woodrow Wilson w orędziu do Kongresu (ang. Congress) z 8 stycznia 1918 r. Idea Wilsona zachowania i zmian ustrojowych Austro-Węgier sformułowana została w punkcie dziesiątym orędzia: „Národom Rakúsko Uhorska, ktorých miesto je medzi národmi, prajem si, aby bolo zabezpečené a zaistené, má sa poskytnút prvá príležitost' na autonómny vývoj"’27.

\section{Koncepcje ustrojowe dotyczące relacji czesko-słowackich we wspólnym państwie}

Ideę wspólnego państwa Czechów i Słowaków, mającego powstać po rozbiciu Austrii i Węgier, podjęły w Stanach Zjednoczonych Ameryki wiodące organizacje słowackiego i czeskiego wychodźstwa, tj. Liga Słowacka (słow. Slovenská liga) ${ }^{28}$ i Czeskie Stowarzyszenie Narodowe (czes. České národní sdružení; słow.

${ }^{25}$ Ibidem, s. 278.

26 Ibidem, s. 282, 284.

${ }^{27}$ R. Letz: Slovenské dejiny..., s. 52; Lexikón slovenských dejín..., s. 125; M.S. Ďurica: Dejiny Slovenska..., s. 282.

${ }_{28}$ Słowacka Liga powstała 26 maja 1907 r. w mieście Cleveland, w stanie Ohio. Ligę powołał do życia, obradujący tam Narodowy Kongres Słowacki (Národný slovenský kongres), w którym wzięło udział około 10 tysięcy działaczy słowackich organizacji i stowarzyszeń. Liga miała być najwyższą organizacją słowacką w Stanach, kierującą życiem politycznym i kulturalnym Słowaków w Ameryce. Pierwszym prezesem Ligi, wybranym przez Kongres, został Štefan Furdek. Kongres wybrał też członków prezydium, zwanych Radą Narodową (Národná rada). (M.S. Ďurica: Dejiny Slovenska..., s. 265-266). Datę powołania Ligi (26 maja 1907 r.) 
České národné združenie). Tak doszło do zawarcia w Cleveland, w stanie Ohio, 23 października 1915 r. Umowy Clevelandzkiej, przewidującej federacyjną formę mającego powstać wspólnego państwa Czechów i Słowaków.

Stanowisko T.G. Masaryka w kwestii słowackiej było zmienne. 15 lutego 1915 r. ,adresoval svoje prvé posolstvo Slovákom. Slúbil v ňom úplnú samostatnost' Slovenskej krajiny s vlastným slovenským snemom v Nitre”.

Już jednak w maju tego roku przedstawił brytyjskiemu ministrowi spraw zagranicznych ,memorandum Independent Bohemia, v ktorom ho informoval o svojom programe znovuzřizení Čech jakožto samostatného státu. Tento budúci štát mal zahrnovat' aj Slovensko, lebo Slováci jsou Česi, přes to, že užívají svého nářečí jakožto spisovného jazyka. Toto memorandum predložil aj francúzskej vláde" 29 .

W październiku 1915 r. zmienił zdanie, akceptując tekst Umowy Clevelandzkiej, przewidującej federacyjny ustrój Republiki Czesko-Słowackiej.

Umowy Pittsburskiej, z 30 maja 1918 r., z treści której można wyciągnąć wniosek, że Słowacja będzie miała we wspólnym państwie status autonomiczny, długo nie podpisywał. W końcu, na naleganie prezesa Słowackiej Ligi, Alberta Mamateya, ją podpisał.

Wreszcie, w latach dwudziestych, w ostrym sporze ze słowackimi autonomistami, reprezentowanymi przez księdza Andreja Hlinkę, twierdził, że Umowa jest nieważna.

Idea jednolitego narodu czechosłowackiego sformułowana została po raz pierwszy w maju 1917 r., w deklaracji czeskich posłów wiedeńskiej Rady Państwa (Reichsrat) o federalizacji Austro-Węgier. W realizacji tej zasady posłowie postulowali przyłączenie Słowacji do ziem czeskich ${ }^{30}$. Nieco wcześniej — w lutym 1916 r. — z Czeskiego Komitetu Zagranicznego (Český zahraničný komitét) w Paryżu powstała Czechosłowacka Rada Narodowa (czes. Československá národní rada; słow. Československá národná rada).

Rada składała się z trzech osób. Jej przewodniczącym był T.G. Masaryk, późniejszy prezydent Republiki; wiceprzewodniczącym M.R. Štefánik, Słowak, obywatel francuski, astronom, francuski generał, pilot, twórca legionów czesko-słowackich; sekretarzem - E. Beneš. Rada miała swoją siedzibę w Paryżu. Warto podkreślić, że Czechosłowacka Rada Narodowa miała swoje oddziały w Rosji, Stanach Zjednoczonych i we Włoszech. Wydawała czasopismo „La Nation tchécque” i „Československá samostatnost”. W programie Rady była likwidacja Austro-Węgier i utworzenie niezależnego państwa Czechów i Słowaków.

należy podkreślić, a to w związku z tym, że jednym z argumentów dla tezy T.G. Masaryka o nieważności Umowy Pittsburskiej (z 30 maja 1918 r.), podnoszonych w latach dwudziestych w sporze o autonomię Słowacji, było twierdzenie Masaryka, że 30 maja 1918 r. Słowacka Liga prawnie nie istniała.

${ }^{29}$ M.S. Ďurica: Dejiny Slovenska..., s. 277.

${ }^{30}$ Ibidem, s. 281. 
Program Rady przyjęły — na wiosnę 1918 r. - mocarstwa ententy, uznając ją, 29 czerwca 1918 r., za reprezentantkę Czechów i Słowaków ${ }^{31}$.

W dniu 14 października 1918 r. Czechosłowacka Rada Narodowa przekształciła się w tymczasowy rząd (czes. prozatimní vláda; słow. dočasná vláda). Inaczej niż w Radzie przedstawiały się w rządzie funkcje: E. Beneš został ministrem spraw zagranicznych i wewnętrznych; T.G. Masaryk - premierem i ministrem finansów; M.R. Štefánik ministrem wojny. Autor tych ważnych zmian ustrojowych, E. Beneš, mianował jednocześnie pięciu ambasadorów: Štefana Osuskiego (w Londynie), Leva Sychravę (w Paryżu), Borskiego (w Rzymie), Perglera (w Waszyngtonie) i Bohdana Pavlů (w Sankt Petersburgu) ${ }^{32}$.

18 października 1918 r. T.G. Masaryk wydał w Waszyngtonie Deklarację Waszyngtońską (Washingtonská deklarácia), oficjalna nazwa: Vyhlášení nezávislosti československého národa dočasnou vládou Československa [...]. Czecho-Słowacja powstała więc formalnie za granicą, bez zgody mieszkańców terytoriów, do których jego twórcy występowali z roszczeniami ${ }^{33}$.

\section{Clevelandská dohoda (22-23 października 1915 r.)}

13 i 14 marca 1915 r. konferencja delegatów czeskich towarzystw w Cleveland (w stanie Ohio) powołała Czeskie Stowarzyszenie Narodowe (České národní sdružení; słow. České národné združenie) jako wiodący organ Czechów żyjących w Stanach Zjednoczonych. W drugim dniu wspólnej konferencji Czeskiego Stowarzyszenia Narodowego i Ligi Słowackiej (Slovenská liga) w mieście Cleveland doszło do podpisania Umowy Clevelandzkiej (Clevelandská dohoda), przewidującej połączenie narodów słowackiego i czeskiego w państwie o ustroju federacyjnym. Autorem projektu Umowy był sekretarz Czeskiego Stowarzyszenia Narodowego Josef Tvrzický. Z czeskiej strony Umowę podpisali: Josef Tvrzický i Ludek Fisher; a ze słowackiej: Albert Mamatey. Przedstawiciele Stowarzyszenia oświadczyli, że T.G. Masaryk Umowę akceptuje.

Umowa miała następującą treść i formę:

Clevelandská dohoda

1. Samostatnost' zemí Českých a Slovenska.

2. Spojenie Českého a Slovenského národa vo federatívnom zväzku štátov, s úplnou autonómiou Slovenska, vlastným snemom, vlastnou štátnou správou,

${ }^{31}$ D. Škvarna: Československá Národná Rada. In: Lexikón slovenských dejín..., s. 197198.

${ }^{32}$ E.K. Kautský: Kauza Štefánik. Legendy, fakty, otázniky okolo vzniku Česko-Slovenskej republiky. Bratislava 2007, s. 210-211.

${ }^{33}$ M.S. Ďurica: Dejiny Slovenska..., s. 287. 
úplnou kultúrnou slobodou, teda i s úplným užívaním jazyka slovenského, vlastnou správou finančnou a politickou, so štátnym jazykom slovenským.

3. Volebné právo: všeobecné, tajné, priame.

4. Forma vlády: personálna únia, s demokratickým zriadením štátu, podobne ako v Anglii.

5. Tieto body tvoria základ predloženej obapolnej dohody a môžu byt' doplnené, pot’ažne rozšírené, len na základe dorozumenia sa oboch stránok. České Národní Sdružení, podržuje si právo prípadnej zmeny a to samé právo má aj Slovenská Liga ${ }^{34}$.

\section{Pittsburghská dohoda (30 maja 1918 r.)}

Česko Slovenská Dohoda, uzavretá v Pittsburghu, Pa., dňa 30. mája, 1918. Predstavitelia slovenských a českých organisácií vo Spoj. Štátoch, Slovenskej Ligy, Českého Národného Sdruženia a Sväzu Českých Katolíkov, porokovali za prítomnosti predsedu Česko Slovenskej Nár. Rady, prof. Masaryka, o česko slovenskej otázke a o našich posavádnych programových prejavoch a usniesli sa nasledovne:

Schval'ujeme politický program usilujúci sa o Spojenie Čechov a Slovákov v samostatnom štáte z českých Zemí a Slovenska.

Slovensko bude mat' svoju vlastnú administratívu, svoj snem a svoje súdy.

Slovenčina bude úradným jazykom v škole, $\mathrm{v}$ úrade a vo verejnom živote vôbec.

Česko slovenský štát bude republikou, jeho Konštitúcia bude demokratická.

Organisácia spolupráce Čechov a Slovákov vo Spoj. Štátoch bude podla potreby a meniacej sa situácie, pri spoločnom dohovorení, pre híbená a upravená.

Podrobné ustanovenia o zriadení československého štátu ponechávajú sa osvobodeným Čechom a Slovákom a ich právoplatným predstavitel'om ${ }^{35}$.

Zawarta w Pittsburgu, w stanie Pensylwania, Umowa była wynikiem rozmów Słowackiej Ligi, Czeskiego Stowarzyszenia Narodowego i Związku Czeskich Ka-

34 J. Tibenský [a kol.]: Slovensko. 1: Dejiny. Bratislava 1971, s. 632; L. Hubenák: Právne dejiny..., s. 103; Lexikón slovenských dejín..., s. 125; M.S. Ďurica: Dejiny Slovenska..., s. 278-279; E.K. Kautský: Kauza Štefánik..., s. 182; R. Letz: Slovenské dejiny..., s. 38-39.

${ }^{35}$ R. Letz: Slovenské dejiny..., s. 62-63. 
tolików (Zväz českých katolíkov) z prezesem Czechosłowackiej Rady Narodowej T.G. Masarykiem. Umowa była wynikiem konieczności jednolitego postępowania Słowaków i Czechów oraz CSRN jako naczelnego organu oporu. Miała uspokoić spory i polemiki o jednym czy dwóch narodach i pokazać, że w przyszłym państwie nie będzie sporów między Czechami i Słowakami. Dokument ma nazwę Česko-Slovenská dohoda. Zgodnie z Umową, Słowacja miała mieć własną administrację, swój sejm i sądy. Była to więc jasna obietnica autonomii i samorządności Słowacji. Język słowacki miał być językiem urzędowym w szkołach, urzędach i w życiu publicznym. Umowę podpisało w sumie 17 Słowaków i 12 Czechów, obywateli amerykańskich (tylko jeden sygnatariusz miał obywatelstwo węgierskie) ${ }^{36}$.

Po kilku latach będzie to dla prezydenta Masaryka jeden z argumentów, potwierdzających nieważność Umowy. Umowa nie przewidywała już federacyjnej formy nowego państwa - inaczej niż Umowa Clevelandzka, przyznając Słowacji status autonomiczny. W tekście Umowy nie ma mowy o słowackiej autonomii. Jej autonomię można jednak wyprowadzić z formuły: „Słowacja będzie miała swoją własną administrację, swój sejm i swoje sądy. Język słowacki będzie językiem urzędowym w szkołach, urzędach i w ogóle w życiu publicznym" ${ }^{37}$.

Zdaniem L. Hubenáka: Umowa ta miała znaczenie tylko polityczne, nie prawne, gdyż o przyszłej formie czechosłowackiego państwa mogły zadecydować jedynie jego konstytucyjne organy ${ }^{38}$.

\section{Prawne podstawy granic Republiki Czechosłowackiej}

\section{Granica wschodnia Republiki Czechosłowackiej}

W amerykańskim Homestead powstała - 23 lipca 1918 r. - Amerykańska Rada Narodowa Uhro-Rusinów, dążąca do zjednoczenia liczebną rusińską emigrację w Stanach Zjednoczonych. 12 listopada 1918 r. zwołany został Kongres Rady. Z 1113 delegatów za przyłączeniem Rusi do Czecho-Słowacji, pod warunkiem przyznania jej autonomii, opowiedziało się $66,42 \%$, za przyłączeniem do Ukrainy $28,13 \%$, za odrębnością państwową $2,43 \%$, za połączeniem z Rusinami z Galicji i Bukowiny $1,18 \%$, za połączeniem z Rosją 0,9\%, za przyłączeniem do Węgier $0,81 \%$, wreszcie za połączeniem z Galicją głosował jeden delegat ${ }^{39}$. Prawną podstawę przyłączenia do Czechosłowacji Podkarpackiej

\footnotetext{
${ }^{36}$ Ibidem, s. $62-63$.

${ }^{37}$ L. Hubenák: Právne dejiny..., s. 103.

${ }^{38}$ Ibidem, s. 104.

${ }^{39}$ R. Letz: Slovenské dejiny..., s. 67.
} 
Rusi - jako terytorium autonomicznego - stanowił traktat pokojowy z Węgrami, zawarty 4 czerwca 1920 r. w Trianon ${ }^{40}$. Przepisy traktatu, dotyczące autonomii Rusi, powtórzył § 3 konstytucji Republiki Czechosłowackiej z 29 lutego 1920 r. Centralistyczna polityka czechosłowackiego rządu spowodowała jednak, że autonomia Podkarpackiej Rusi stała się rzeczywistością dopiero w jesieni 1938 r. Nie do końca jednak, gdyż na obszar Rusi weszły wówczas wojska węgierskie, zajmując zachodnią Ruś wraz z Użgorodem ${ }^{41}$. Stolicą Rusi stało się wówczas, leżące w pobliżu Cisy (węg. Tisza), miasto Chust.

Południową granicę Słowacji określała najpierw tymczasowa linia demarkacyjna, ustalona 6 grudnia 1918 r. umową delegata rządu Milana Hodžy z węgierskim ministrem wojny Albertem Barthą. Niekorzystna dla Słowacji linia demarkacyjna, pozostawiająca po węgierskiej stronie Bratislavę, Nové Zámky, Levice, Lučenec, Rožňavę i Košice, obowiązywała krótko. Już bowiem 24 grudnia 1918 r. pułkownik Ferdinand Vix, szef francuskiej misji wojskowej, przekazał węgierskiemu rządowi ustaloną przez sprzymierzeńców definitywną linię graniczną między Słowacją i Węgrami ${ }^{42}$. Ta, korzystniejsza dla Słowacji, granica pokrywa się w zasadzie z dzisiejszą granicą. Traktat z Trianon (4 czerwca 1920 r.) przyłączył Słowację do Republiki Czechosłowackiej, nie zmieniając ustalonej w końcu grudnia 1918 r. granicy państwowej.

\section{Północna granica Słowacji}

Zajmowanie Słowacji nie było proste, gdyż wojsko węgierskie stawiało armii czechosłowackiej poważny opór. Nadto pojawiły się — z polskiej strony — roszczenia terytorialne do Ziemi Czadeckiej, Spisza i Orawy ${ }^{43}$. Po rezygnacji obu stron z plebiscytu, wyznaczonego już na Śląsku Cieszyńskim, Spiszu i Orawie na dzień 24 lipca 1920 r., ostatecznie o podziale tych terytoriów zadecydowała 28 lipca 1920 r. — w belgijskim Spaa — Rada Ambasadorów ${ }^{44}$; a o przynależności Jaworzyny - Rada Ligi Narodów w 1924 r. ${ }^{45}$.

O granicy południowej Czech i Moraw zadecydował traktat pokojowy z Austrią, podpisany 10 września 1919 r. w Saint Germain en Laye. „ČSR dosiahla

${ }^{40}$ M. Skaloš: Proces utvárania Slovenských hranic ako štátnych hranic ČSR (historické a právne aspekty). „Z Dziejów Prawa” 2012, T. 5 (13), s. 143.

${ }^{41}$ P. Mosný: Podkarpatská Rus. Nerealizovaná autonómia. Bratislava 2001. Rec. J. Ciągwa. „Czasopismo Prawno-Historyczne” 2003, T. 55, z. 1, s. 478-480.

${ }^{42}$ R. Letz: Slovenské dejiny..., s. 99.

${ }^{43}$ Ibidem.

${ }^{44}$ J. Klimko: Vývoj územia Slovenska a utváranie jeho hraníc. Bratislava, s. 118; A. Ajnenkiel: Plebiscyty w Polsce $i$ w Europie po I wojnie światowej. W: Z perspektywy sześćdziesięciu lat. [Red. H. Janowska, M. Nowak-Kiełbikowa]. Warszawa 1982, s. 301; M.S. Ďurica: Dejiny Slovenska..., s. 316; M. Skaloš: Proces..., s. 143, 146.

${ }^{45}$ M. Skaloš: Proces..., s. 144, 146. 
zmluvou niektoré rektifikácie hraníc proti Rakúsku (čast'Vitorázska a Valticko)" ${ }^{\text {46 }}$.

Zachodnią granicę Republiki Czechosłowackiej ustalił traktat pokojowy z Niemcami, zawarty w Wersalu 28 czerwca 1919 r. Traktat włączył do Czechosłowacji małą część Górnego Śląska, tj. Okręg Hulczyński (Hlučínsko; niem. Hlutschiner Gau), czego konsekwencją była recepcja trzeciego porządku prawnego (poza austriackim w Czechach, na Morawach, Śląsku Opawskim i Cieszyńskim; i węgierskim na Słowacji i Rusi Podkarpackiej), tj. prawa niemieckiego. Trializm porządku prawnego trwał krótko, do roku 1923. Prace Ministerstwa Unifikacji Ustaw i Organizacji Administracji doprowadziły w roku 1923 do rozciągnięcia prawa austriackiego na Okręg Hulczyński.

\section{Powstanie Republiki Czechosłowackiej}

Wieczorem 28 października 1918 r. przedstawiciele Czeskiego Komitetu Narodowego (Český národný výbor) wydali ustawę o utworzeniu niezależnego państwa czesko-słowackiego. Projekt ustawy był dziełem Aloisa Rašína, wykorzystującym przygotowany wcześniej tekst prawnika Ferdynanda Pantůčka. Ustawę podpisali: Antonín Švehla, Jiří Střibrný, Alois Rašín, František Soukup, a w imieniu Słowaków Vavro Šrobár ${ }^{47}$. W wykazie 42 członków Czeskiego Komitetu Narodowego znajdują się dwa słowackie nazwiska: Matúš Dula i Vavro Šrobár. Na Słowacji nic o tym nie wiedziano, co więcej, nie wiedziało o tym nawet dwóch mianowanych „członków” tego komitetu ${ }^{48}$.

30 października 1918 r. - na zaproszenie prezydium Słowackiej Partii Narodowej (Slovenská národná strana) — zebrało się na naradzie w Turczańskim św. Marcinie (słow. Turčiansky sv. Martin; węg. Turociszentmárton) - 101 słowackich działaczy politycznych. Uczestnicy zgromadzenia ogłosili się „Radą Narodową słowackiej gałęzi jednolitego narodu czechosłowackiego" i uchwalili Deklarację narodu słowackiego (Deklarácia slovenského národa), którą Słowacja przyłączyła się do państwa czesko-słowackiego. Autorem projektu Deklaracji był Samuel Zoch.

Zdaniem M.S. Duricy, Słowacka Rada Narodowa nie stanowiła reprezentacji całego słowackiego narodu, gdyż spośród 101 uczestników narady, z których 95 było ewangelików, a $31 \mathrm{z}$ nich z Turczańskiego św. Marcina. Tymczasem słowackich katolików, stanowiących około 84\% mieszkańców Słowacji, reprezen-

\footnotetext{
46 Ibidem, s. 143.

47 R. Letz: Slovenské dejiny..., s. 85.

${ }^{48}$ M.S. Ďurica: Dejiny Slovenska..., s. 288.
} 
towało kilka (tj. sześciu) wybitnych osobistości, tworzących nieznaczną mniejszośśc ${ }^{49}$. Zgromadzenie wybrało 20 członków Rady, a spośród niej 12-osobowy Wydział Wykonawczy (Výkonný výbor). Liczba członków Rady mogła ulec poszerzeniu maksymalnie do 100 .

Jednym z najważniejszych postanowień Deklaracji ${ }^{50}$, sformułowanym na jej początku, był przepis o charakterze kompetencyjnym: „Národná Rada vyhlasuje, že v mene česko-slovenského národa bývajúceho $\mathrm{v}$ hraniciach Uhorska, je jedine ona oprávnená hovorit' a konat'" ${ }^{51}$. Przepis ten miał być gwarancją jej autonomicznego statusu prawno-politycznego; oraz niezależności od innych organów tak słowackich, jak i czeskich i węgierskich.

Rozwój późniejszych wydarzeń pokazał, że dr Vavro Šrobár, kierujący Ministerstwem z Pełną Mocą dla Administracji Słowacji (Ministerstvo s plnou mocou pre správu Slovenska), zlikwidował - 8 stycznia 1919 r. — Słowacką Radę Narodową (i lokalne rady narodowe), administrując Słowacją zgodnie z wolą swoich praskich mocodawców. Faktycznie i prawnie Republika Czechosłowacka powstała więc - już 28 października 1918 r. — decyzją Czeskiego Komitetu Narodowego (Český národní výbor) — bez czekania na stanowisko słowackiej reprezentacji, wyrażonej w uchwalonej 30 października 1918 r. w stolicy żupy Turiec (Turčiansky Svätý Martin), Deklaracji Słowackiej Rady Narodowej.

Tak było też nieco później, kiedy 4 listopada 1918 r. Komitet Narodowy w Pradze „,bez jakiegokolwiek kontaktu ze Słowacką Radą Narodową upoważnił... Dr. Vavro Šrobára do mianowania tymczasowego słowackiego rządu (Dočasná slovenská vláda) i tymczasowo był jego prezesem". Zadaniem rządu była „okupacja Słowacji i ogłoszenie państwa czechosłowackiego na terytorium Uherska" 52 .

31 października 1918 r. członkowie Wydziału Wykonawczego Słowackiej Rady Narodowej przedyskutowali kwestie prawno-państwowe tworzącego się państwa. Zasadniczą płaszczyzną dyskusji był projekt czeskiego prawnika Ferdinanda Pantůčka, zakładający przeniesienie systemu administracji publicznej i finansowej, szkolnictwa i sądownictwa z Czech na Słowację ${ }^{53}$; obowiązująca na Słowacji administracja publiczna żup (komitat, megye, stolica) miała być zniesiona i zastąpiona jednolitą administracją polityczną, wzorowaną na czeskiej ${ }^{54}$.

49 Ibidem.

${ }^{50}$ Cały tekst Deklaracji, przyjęty 30 października 1918 r., zob. w: R. Letz: Slovenské dejiny..., s. 89-90.

${ }^{51}$ R. Letz: Slovenské dejiny..., s. 89.

${ }_{52}$ M.S. Durica: Dejiny Slovenska..., s. 291.

${ }_{53}$ R. Letz: Slovenské dejiny..., s. 90.

${ }^{54}$ Ibidem. Ziemie Korony św. Stefana dzieliły się na 63 żupy węgierskie i 8 żup chorwacko-slavońskich. Żupa stanowiła najwyższą jednostkę podziału administracyjno-terytorialnego Węgier, odpowiadającego polskim województwom. I współcześnie Republika Węgierska dzieli się na żupy (węg. megye). Żupy, powstałe w XIII wieku, są dość rzadkim przykładem historycznego (nie racjonalistycznego) podziału administracyjno-terytorialnego państwa. Mimo że po 
Po dyskusji na temat statusu prawnego Słowacji we wspólnym państwie Czechów i Słowaków, Wydział przyjął rozwiązanie kompromisowe, zgodnie z którym „przejściowe rozwiązania dotyczące jednolitego państwa miały obowiązywać najdłużej przez dziesięć lat" ${ }^{55}$, ale czym prędzej miał zostać uregulowany „prawno-państwowy status żyjącej dotąd w Uhersku gałęzi naszego narodu umową między legalnymi przedstawicielami ze Słowacji z jednej strony, z Czech, Moraw i Śląska z drugiej strony" 56.

Czeski Komitet Narodowy, złożony z 256 posłów, niepochodzących z wyborów „,uchwalił - 13 listopada 1918 r. - Tymczasową Konstytucję (czes. Prozatimní ústava; słow. Dočasná ústava), którą przemianował się na Zgromadzenie Narodowe (czes. Národní shromaždení; słow. Národné zhromaždenie), i przyjął do swego składu 14 (tj. 5,18\%) nie pochodzących z wyborów »przedstawicieli Słowacjik.

14 listopada 1918 r. Zgromadzenie Narodowe powołało pierwszy rząd państwa czesko-słowackiego, z premierem Karlem Kramářem. Dwie ministerialne teki otrzymali Słowacy: Vavro Šrobár (zdrowie), i nieobecny Milan Rastislav Štefánik (wojsko)"s7.

Tego samego dnia (14 listopada 1918 r.) Zgromadzenie Narodowe wybrało przez aklamację prezydentem Tomasza Garrigue Masaryka. Równocześnie rozwiązany został - kierowany przez Vavro Šrobára - Tymczasowy Rząd Słowacki (czes. Prozatimní slovenská vláda; słow. Dočasná slovenská vláda), a także zwiększono - do 40 - liczbę ,przedstawicieli Słowacji” w Zgromadzeniu Narodowym, przy czym w tej liczbie było 9 Czechów; a wśród ,posłów słowackich" było zaledwie 4 przedstawicieli 84-procentowej większości słowackich katolików ${ }^{58}$.

utracie przez Węgry - na podstawie traktatu pokojowego, zawartego 4 czerwca $1920 \mathrm{r}$. w Trianon $-72 \%$ terytorium (przed traktatem $325411 \mathrm{~km}$; po traktacie $-93000 \mathrm{~km}$ ) zmienił się znacznie kształt zwłaszcza żup nadgranicznych. Przykładem tych zmian może być potrianońska jednostka administracyjna, istniejąca i obecnie, tj. komitat (megye) Szabolcs — Szatmár Bereg, z ośrodkiem administracyjnym w mieście Nyiregyhaza, powstała z połączenia trzech istniejących przedtem komitatów, znacznie pomniejszonych w wyniku postanowień traktatu pokojowego.

${ }_{55}$ R. Letz: Slovenské dejiny..., s. 90.

${ }_{56}$ M.S. Ďurica: Dejiny Slovenska..., s. 289.

57 Ibidem, s. 292.

58 Ibidem, s. 292. 


\section{Obejmowanie terytoriów nowego państwa}

\section{Obejmowanie ziem czeskich}

$\mathrm{W}$ procesie wcielania istotnym problemem okazały się cztery prowincje zamieszkałe przez Niemców. Wiedeń uznawał je za części składowe Niemieckiej Austrii. Terytoria te zaczęły się formować w prowincje, uznające suwerenność Austrii. Tak na posiedzeniu parlamentu austriackiego - 30 października 1918 r. - powstały prowincje: Deutschböhmen i Sudetenland, a na posiedzeniu 3 listopada 1918 r. prowincje: Deutschsüdmähren oraz Böhmerwaldgau. Każda z prowincji miała swój rząd. W zamyśle Wiednia było związanie tych prowincji nie z Niemiecką Austrią, lecz całej Niemieckiej Austrii z Niemcami. Ostatecznie włączenie czterech prowincji do Republiki Czesko-Słowackiej okazało się stosunkowo łatwe; już przed Bożym Narodzeniem 1918 r. zostało całe terytorium Czech, zamieszkałe przez ludność niemiecką, zajęte przez armię czechosłowacką. Stało się to prawie bez oporu i ofiar śmiertelnych ${ }^{59}$.

\section{Obejmowanie ziem słowackich}

Zajmowanie ziem słowackich okazało się trudniejsze. Przeszkodami w budowaniu integralności terytorialnej Słowacji były próby atomizacji jej terytorium, które przybrały postać Republiki Wschodniosłowackiej, i Słowackiej Republiki Rad (Slovenská republika rád).

Archiwista żupy preszowskiej Viktor Dvorcsák ${ }^{60}$ wraz z pastorem ewangelickim Lajosem Liptayem założyli w Preszowie - 2 grudnia 1918 r. — Radę Wschodnio-Słowacką (Vichodno-slovenská rada; w słowackim języku literackim: Východoslovenská rada), dążącą do połączenia tzw. Słowjaków (Slovjaci) z narodem węgierskim. Według Dvorcsáka Slovjaci są odrębnym narodem, których od zachodnich Słowaków różni język, mentalność i dzieje. W gruncie rzeczy chodziło o utrzymanie wschodniej Słowacji pod kontrolą rządu budapeszteńskiego. Z poparciem węgierskiego ministra narodowości Oszkára Jásziego Dvorcsák - przewodniczący Wschodnio-Słowackiej Rady ogłosił (11 grudnia 1918 r.) — w koszyckiej kawiarni Royal powstanie samoistnej Republiki Wschodniosłowackiej (Východoslovenská republika). Krótkie dzieje Republiki Wschodniosłowackiej dobiegły kresu po kilku dniach jej istnienia, kiedy

\footnotetext{
59 Ibidem, s. 288.

${ }^{60} \mathrm{~W}$ niektórych publikacjach też Dvortsák.
} 
jej przedstawiciele emigrowali na Węgry. Węgierska iredenta wykorzystywała problem wschodnio-słowacki w praktyce do roku $1945^{61}$.

Objęcie ziem słowackich przez armię czechosłowacką zahamował atak węgierskiej armii czerwonej, zbrojnego oręża Węgierskiej Republiki Rad. Niedostateczne przygotowanie armii czechosłowackiej oraz wymiana włoskiej misji wojskowej na francuską spowodowały zajęcie przez wojska węgierskie prawie 2/5 obszaru Słowacji (między innymi miasta: Nové Zámky, Komárno, Levice, Banská Štiavnica, Zvolen, Detva, Lučenec, Košice, Vranov nad Toplou, Prešov, Bardejov). Atak Węgrów rozpoczął się 19 maja 1919 r. na szerokim froncie od Miszkolca (węg. Miskolc; słow. Miškovec) po Szturowo (słow. Štúrovo; węg. Párkány $)^{62}$.

W wyniku niepowodzeń armii czechosłowackiej Vavro Šrobár upoważnił francuskiego generała Mittelhausera, dowódcę zachodniej grupy armii, by ten wprowadził - 5 czerwca 1919 r. - stan wojennej dyktatury. Już 6 czerwca 1919 r. wojsko czechosłowackie zdołało zatrzymać węgierską ofensywę w zachodniej i środkowej Słowacji, i przeszło do kontrofensywy. W ten sposób odzyskano Lewice, Bańską Szczawnicę, Zwolen i Nowe Zamki ${ }^{63}$.

O utworzeniu Słowackiej Republiki Rad (słow. Slovenská republika rád; węg. Szlovak Tanácsköztársaság) zadecydował rząd Węgierskiej Republiki Rad (A Magyar Tanácsköztársaság; słow. Mad’arská republika rád) na posiedzeniu w dniu 4 czerwca 1919 r. Wniosek dotyczący utworzenia Słowackiej Republiki Rad przedłożył Węgierskiej Radzie Rewolucyjnej wódz węgierskich bolszewików Béla Kun ${ }^{64}$; a jej powstanie przyśpieszyła ingerencja (9 czerwca 1919 r.) ludowego komisarza spraw zagranicznych sowieckiej Rosji Georgija V. Cziczerina. Komunistyczna republika powstała 16 czerwca 1919 r. w Preszowie (słow. Prešov ukr. Prjasziw, węg. Eperjes). Na jej czele stał czeski robotnik Antonín Janoušek. Utworzenie przez węgierskich komunistów proletariackiej republiki na słowackiej ziemi było ewidentnym naruszeniem suwerenności czesko-słowackiego państwa. Położona na części wschodniej Słowacji mała republika proklamowała przejęcie władzy na obszarze całej Słowacji. Według Roberta Letza Słowacka Republika

${ }^{61}$ Lexikón slovenských dejín..., s. 130; M.S. Ďurica: Dejiny Slovenska..., s. 291, 295; R. Letz: Slovenské dejiny..., s. 101. Krytyczne uwagi prof. A. Miškoviča o poglądach V. Dvorcsáka, wyrażone na stronach czasopisma „Náš národ”, przedstawiłem w artykule Alojz Miškovič obranca integrity Slovenska. W: Almanach Stowacy w Polsce VII. Almanach Slováci v Pol'sku VII. Kraków/Krakov 2000, s. 31-62.

${ }^{62}$ R. Heck, M. Orzechowski: Historia Czechosłowacji. Wrocław 1969, s. 320; Lexikón slovenských dejín..., s. 131-132; M.S. Ďurica: Dejiny Slovenska..., s. 303; R. Letz: Slovenské dejiny..., s. 111; L. Kościelak: Historia Słowacji. Wrocław 2010, s. 313. „Na územie Slovenska začali prenikat' mad’arské ozbrojené skupiny, komandované z Lučenca a z Košíc, kde sa prenieslo vedenie českej a slovenskej sekcie mad’arskej socialisticko — komunistickej strany". (M.S. Ďurica: Dejiny Slovenska..., s. 303).

${ }^{63}$ R. Letz: Slovenské dejiny..., s. 112.

${ }^{64}$ M.S. Durica: Dejiny Slovenska..., s. 304. 
Rad stanowiła subsystem Węgierskiej Republiki Rad. Właściwszym określeniem byłaby więc nazwa: Republika Rad na Słowacji ${ }^{65}$. Węgierscy komuniści wprawdzie uznawali na zewnątrz Słowacką Republikę Rad za sprzymierzeńca, praktycznie jednak chodziło im o realizację planów odbudowy integralności Uherska, jeśli nawet nie na podstawie idei świętostefańskiej, to na bazie rewolucji i solidarności proletariackiej ${ }^{66}$.

Reformy polityczne, społeczne, gospodarcze i kulturalne, przeprowadzone przez władze Słowackiej Republiki Rad (uspołecznienie środków produkcji i wywłaszczenie obszarników; reformy w zakresie polityki socjalnej, szkolnictwa, oświaty i propagandy; reformy w zakresie sądownictwa i bezpieczeństwa) naśladowały ściśle wzory Węgierskiej Republiki Rad i wzory rosyjskich sowietów ${ }^{67}$. „Marksistowska historiografia i publicystyka stworzyła po roku 1948 z krótkiego epizodu istnienia Słowackiej Republiki Rad mit o pierwszym rzeczywistym państwie robotników i rolników na naszym terytorium" ${ }^{68}$. Rządy bolszewickiej Republiki cechował niesłychany terror, zwłaszcza młodych bolszewików węgierskich, zwanych dziećmi Lenina (Lenin gyermekei; Leninové detí) ${ }^{69}$.

Węgierska Republika Rad akceptowała nową linię demarkacyjną, ustaloną w Paryżu 11 czerwca 1919 r. Nowa linia demarkacyjna pokrywała się z granicami ustalonymi później w Trianońskim Traktacie Pokojowym z 4 czerwca 1920 r.

24 czerwca 1919 r. wstrzymano walki, a w Bratysławie (słow. Bratislava; węg. Pozsony; niem. Pressburg) rozpoczęły się rozmowy o wyprowadzeniu węgierskiego wojska ze Słowacji. Między 30 czerwca a 4 lipca 1919 r. armia węgierska opuściła okupowane słowackie ziemie ${ }^{70}$. W lecie 1919 r. przyłączono do Bratysławy Petržalkę, leżącą po drugiej stronie Dunaju ${ }^{71}$.

Podczas gdy zajęcie ziem czeskich, zamieszkałych przez Niemców, odbyło się bez poważniejszych komplikacji, na Słowacji trwały — z większą lub mniejszą intensywnością — walki od początku listopada 1918 r. do końca czerwca 1919 r. O ile w czeskiej części państwa sytuacja skonsolidowała się na tyle, że w czerwcu 1919 r. jej mieszkańcy wzięli udział w wyborach gminnych, (pol. gmina; słow. obec; niem. Gemeinde; węg. község), to na Słowacji stan wyjątkowy zniesiono dopiero $\mathrm{w}$ roku $1920^{72}$.

65 Ibidem.

66 Ibidem.

${ }^{67}$ J. Klimko: Slovenská republika rád. (Pokus o socialistickú štátnost'). Bratislava 1979, S. $93-102$.

68 R. Letz: Slovenské dejiny..., s. 113.

69 Drastyczne przykłady terroru przedstawił M.S. Ďurica: Dejiny Slovenska..., s. 304308; R. Letz: Slovenské dejiny..., s. 113.

70 R. Letz: Slovenské dejiny..., s. 112-113.

71 Ibidem.

72 Ibidem, s. 112-114. „Bol’ševická hrôzovláda na značnej časti územia Slovenska trvala asi tri týždne. [...] Posledné mad’arské bol’ševické vojenské jednotky a ich teror riadiaci politickí komisári 7. júla opustili Slovensko”. (M.S. Ďurica: Dejiny Slovenska..., s. 305). 


\section{Spór o ważność Umowy Pittsburskiej}

Zawarta w Pittsburgu (w stanie Pensylwania) 30 maja 1918 r. Umowa stanowiła dla Słowackiej Partii Ludowej (Slovenská l’udová strana) i jej działaczy podstawę do wprowadzenia w życie jej postanowień dotyczących autonomii Słowacji. Dlatego niezwykle istotne było ustalenie, czy Umowa ta jest ważna, a tym samym czy obowiązuje.

Jak już była o tym mowa, prezydent Masaryk twierdził stanowczo, że Umowa nie jest ważna i że nie ma mocy obowiązującej, mimo że sam był jej autorem i że ją podpisał. Przeciwne stanowisko zajmowali słowaccy autonomiści z jej prezesem, księdzem Andrejem Hlinką; a w Stanach Zjednoczonych — Słowacy reprezentowani przez Słowacką Ligę.

W sporze o Umowę prezydent Masaryk podnosił następujące argumenty, świadczące - jego zdaniem - o nieważności Umowy: 1. Umowę zawarli Czesi i Słowacy, będący obywatelami Stanów Zjednoczonych Ameryki. Ponadto wskazywał, że spośród sygnatariuszy Umowy tylko jeden czy dwóch miało obywatelstwo austriackie bądź węgierskie ${ }^{73} ; 2$. Słowacka Liga, której przedstawiciele podpisali Umowę, nie miała statutu; 3. Umowa została zawarta 30 maja 1918 r. w dniu święta państwowego Memorial Day, a nie w dniu powszednim.

Zbijając pierwszy argument Masaryka, Robert Letz wskazuje słusznie na fakt, że generał Milan Rastislav Štefánik był obywatelem francuskim, a mimo to liczne, podpisywane przez niego umowy o charakterze międzynarodowym były powszechnie uznawane za ważne i obowiązujące ${ }^{74}$.

Nie jest zgodne $z$ prawdą twierdzenie pierwszego prezydenta Republiki, że Umowa Pittsburska nie obowiązuje, gdyż została zawarta w dniu święta państwowego Memorial Day. Nieważność aktów prawnych, zawartych w dniu święta państwowego, dotyczy bowiem umów prywatnych i handlowych, a nie dokumentu o charakterze publicznym, jakim bez wątpienia była Umowa Pittsburska.

Bez znaczenia jest też argument Masaryka, że statut (słow. stanovy) Słowackiej Ligi został uchwalony dopiero w 1919 r. „Slovenská liga vznikla už roku 1907. V USA neplatil rakúsky štátny byrokratizmus. Schval'ovanie stanov sa tu striktne nevyžadovalo, a to najmä u neziskových záujmových organizácií, akou bola Slovenská liga"75. Stanowisko takie potwierdził w roku 1930 wybitny prawnik amerykański Geo E. Alter, były prokurator stanu Pensylwania i prezes izby adwokackiej. Według niego, Słowacka liga ,, čase uzavretia zmluvy bola

${ }^{73}$ Zapomniał zresztą dodać, że trzecim, nieamerykańskim sygnatariuszem był on sam, będąc w tym czasie obywatelem austriackim.

${ }^{74}$ R. Letz: Slovenské dejiny..., s. 66.

${ }^{75}$ Ibidem. 
organizáciou, majúcou ústavu, stanovy, úradníkov atd’, hoci nebola čarterovaná [...]. Zmluva (záväzok, dohoda), uzavretá touto nečarterovanou organizáciou, je celkom tak právoplatná a záväzná, ako by bola bývala uzavretá čarterovanou organizáciou a práve tak platná, ked’že uzavretá v úradný sviatok (Memorial Day) ako v hociktorý všedný deň"76.

Autorzy czeskich dziejów prawa nie zajęli stanowiska w kwestii ważności Umowy Pittsburskiej. Stwierdzali jedynie, że „koncepcja czechosłowakizmu negowała program pittsburski, przez co Umowa stała się - od powstania Czechosłowacji - trwałym ogniskiem politycznych napięć"

Nie powiodła się próba słowackich autonomistów włączenia Umowy do konstytucji Republiki: 10 czerwca 1920 r. poseł Słowackiej Partii Ludowej Dr. Ferdiš Juriga wnioskowal w Zgromadzeniu Narodowym o włączenie tekstu Umowy Pittsburskiej do ustawy zasadniczej państwa. Ale „návrh neprešiel ani do diskusie v parlamente" ${ }^{78}$.

\section{Czechosłowakizm (Čechoslovakizmus) Naród czeskosłowacki (Československý národ)}

Czechosłowakizm to kierunek ideowy i polityczny, który wyrażał przekonanie, że Czesi i Słowacy tworzą jeden naród. Zasady tego kierunku formowały się już od końca XVIII w. w środowisku czeskich i części słowackich, zwłaszcza ewangelickich działaczy odrodzenia narodowego ${ }^{79}$.

W pierwszej połowie XIX w. kierunek był znany twórcy idei wzajemności słowiańskiej (łac. reciprocitas slavica; niem. slawische Wechselseitigkeit; słow. slovanská vzájomnost') Jánowi Kollárowi, który - inspirowany filozofią J.G. Herdera - stworzył pojęcie narodu słowiańskiego, złożonego z czterech szczepów (słow. kmeň): rosyjskiego, polskiego, czechosłowackiego i iliryjskiego. Język czechosłowacki był czymś oczywistym także dla szturowców, wykładowców i studentów Ewangelickiego Liceum Języka i Literatury Czechosłowackiej ${ }^{80}$.

\footnotetext{
76 Ibidem.

77 L. Vojáček, K. Schelle, V. Knoll: České právni dějiny. Plzeň 2010, s. 286.

78 M.S. Ďurica: Dejiny Slovenska..., s. 316.

79 R. Letz: Čechoslovakizmus. In: Lexikón slovenských dejín..., s. 196.

${ }^{80}$ J. Ciągwa: Słowacka ideologia narodowa na przełomie: Ludovit Štúr (1815-1856).
} [Niepublikowana rozprawa doktorska napisana pod kierunkiem prof. dr. hab. Jana Baszkiewicza, obroniona na Uniwersytecie Śląskim]. Katowice 1971, passim. W języku czechosłowackim prowadzono wykłady, już w roku 1810, w Katedrze języka czechosłowackiego w Liceum w Bańskiej Szczawnicy. (M.S. Ďurica: Dejiny Slovenska..., s. 179). 
Definitywną formę czechosłowakizm uzyskał pod koniec XIX w. Kierunek ten negował istnienie odrębnego narodu słowackiego. Głosił, że Słowacy mają zrezygnować z własnego narodowgo bytu (pierwotnie także z języka literackiego). Takie stanowisko uzasadniano tym, że czeskie środowisko jest pod względem kulturalnym i ekonomicznym bardziej rozwinięte, oraz tym, że słowaccy ewangelicy — już tradycyjnie — używali biblijnego języka czeskiego jako języka liturgii. Na przełomie XIX i XX w. nurt ten znalazł kontynuatorów wśród hlasistów i prudystów (hlasisti; prúdisti) ${ }^{81}$. Po roku 1918 czechosłowakizm stał się oficjalną polityką i ideologią państwową, regulowaną prawnie w konstytucji z 29 lutego (czes. únor; słow. február). Istniał w etnicznej i politycznej formie. Powszechny spis ludności (słow. sčítanie l’udu) z 1921 r. wymieniał oficjalnie jedynie narodowość czechosłowacką. Propagatorami idei czechosłowakizmu byli prezydent Masaryk i jego następca - prezydent Eduard Beneš. Ten drugi, po powrocie z Londynu, prezydent uzurpator ${ }^{82}$, do końca życia — zmarł w 1948 r. twierdził, że nie ma słowackiego narodu i odrębnego języka słowackiego. Jeszcze w Londynie, 16 grudnia 1943 r., oświadczył: „Mne nikdy nedostanete k tomu, abych uznal slovenský národ. Je to mé vědecké přesvědčení, které nezměním [...] zastávám neochvějně názor, že Slováci jsou Češi a že slovenský jazyk jest jen jedním z nářečí českého jazyka, tak jako tomu je s hanáčtinou"83.

Taki sam pogląd prezentował mistrz Beneša - Tomáš G. Masaryk: 14 września 1921 r. w wywiadzie dla francuskiego dziennika „Le Petit Parisien” Masaryk powiedział: „Niet slovenského národa, to je výmysel mad’arskej propagandy”. A potem dodał: „Zakládame na Slovensku školy. Musíme počkat na ich výsledky. O jednu generáciu nebude rozdielu medzi dvoma vetvami nášho národa" ${ }^{94}$. $\mathrm{Na}$ Słowacji najbardziej znanymi sprzymierzeńcami czechosłowakizmu byli Vavro Šrobár i Ivan Dérer. Ideologia czechosłowakizmu okazała się wyjątkowo odporna na korozję. Jeszcze w marcu 1991 r., w czasie ostatniego przed rozpadem

${ }^{81}$ Hlasisti to grupa młodych liberałów słowackich (główni działacze: Vavro Šrobár, Pavol Blaho, Fedor Houdek, częściowo także Milan Hodža), studiujących w Pradze, inspirowanych zwłaszcza poglądami T.G. Masaryka. Nazwa grupy pochodzi od tytułu wydawanego przez nią — od roku 1898 - czasopisma: „Hlas” (pol. głos). (D. Škvarna: Hlasisti. In: Lexikon slovenských dejín..., s. 216-217); M.S. Ďurica: Dejiny Slovenska..., s. 253.

Prúdisti - młodsza generacja słowackich liberałów, nawiązująca do poglądów hlasistów, sformowana w sierpniu 1909 r., wydająca czasopismo „Prúdy” (pol. prądy, kierunki, nurty). (D. Škvarna: Hlasisti...).

${ }^{82}$ Literatura omija ten problem. Moim zdaniem nazwanie E. Beneša prezydentem uzurpatorem uzasadniają trzy fakty: 1. abdykacja prezydenta (5 października 1938 r.); 2. upływ siedmioletniej kadencji prezydenckiej; 3. brak ponownego wyboru. Beneš oświadczył publicznie, że na emigrację udaje się jako osoba prywatna. Już wtedy złożył gratulacje nowemu prezydentowi, którym był prof. Emil Hácha. Jedynie M.S. Ďurica nazywa Beneša samozwańcem (Jozef Tiso 1887-1947. Životopisný profil. Bratislava 2006, passim).

${ }^{83}$ R. Letz: Slovenské dejiny..., s. 271.

${ }^{84}$ M.S. Durica: Dejiny Slovenska..., s. 323. 
federacji spisu ludności, „narodowość czechosłowacką” deklarowały w Republice Czeskiej 3464 osoby, a w Republice Słowackiej 59 osób ${ }^{85}$.

W okresie międzywojennym po przeciwnej stronie stanęli obrońcy idei odrębności narodu słowackiego, a zarazem przeciwnicy czechosłowakizmu: Słowacka Partia Ludowa Hlinki (Hlinkova slovenská l'udová strana), Słowacka Partia Narodowa (Slovenská národná strana), a przez pewien czas werbalnie także Komunistyczna Partia Czechosłowacji (Komunistická strana Československa).

Niepochodzące z wyborów Tymczasowe Zgromadzenie Narodowe uchwaliło - 29 lutego 1920 r. — konstytucję, ustawę językową oraz inne ważne ustawy. Preambułę (arengę) konstytucji, wzorowaną na preambule konstytucji USA z 17 września 1787 r., otwiera zwrot „My národ Československý”. To jasne zwycięstwo idei czechosłowakizmu i klęski kierunku uznającego Słowaków za samoistny, odrębny naród.

W końcowym fragmencie preambuły termin „naród czechosłowacki” pojawia się jeszcze raz: „Při tom my, národ československý, prohlašujeme, že chceme usilovati, aby tato ústava i všechny zákony naší země prováděny byly $\mathrm{v}$ duchu našich dějin, stejně jako v duchu moderních zásad, obsažených v hesle sebeurčení" $"$.

Czechosłowakizm wyziera też jednoznacznie $\mathrm{z}$ - uchwalonej tego samego dnia — konstytucyjnej ustawy językowej, stanowiącej, że „państwowym oficjalnym językiem republiki jest język czeskosłowacki”"87.

Zgodnie z uchwaloną 29 lutego 1920 r. ustawą językową, mniejszości narodowe miały prawo używania swojego języka narodowego w urzędach i sądach, położonych w tych powiatach (słow. okres), w których mniejszość stanowiła więcej niż $20 \%$ mieszkańców ${ }^{88}$.

Konfrontacja przepisów ustawy językowej, dotyczących $-\mathrm{z}$ jednej strony - Słowaków, a z drugiej strony - mniejszości narodowych, pokazuje, że Słowakom jako narodowi państwowotwórczemu, ustawa, wprowadzająca język czeskosłowacki, a więc język fikcyjny i nieistniejący, przyznała mniej praw niż mniejszościom narodowym.

Uzupełnienia i zmiany programów nauczania szkół średnich w Czechach, na Morawach i Śląsku, wydane 11 września 1919 r. przez Ministerstwo Szkolnictwa i Narodowej Oświaty w Pradze, wprowadziły jako język nauczania język czeski, natomiast na Słowacji język czeskosłowacki ${ }^{89}$.

\footnotetext{
${ }^{85}$ R. Letz: Čechoslovakizmus..., s. 196.

${ }^{86}$ Lexikón slovenských dejín..., s. 133; R. Letz: Slovenské dejiny..., s. 115-116.

${ }^{87}$ Lexikón slovenských dejín..., s. 133; M.S. Duurica: Dejiny Slovenska..., s. 313-314; R. Letz: Slovenské dejiny..., s. 115.

${ }^{88}$ Lexikón slovenských dejín..., s. 133.

89 M.S. Ďurica: Dejiny Slovenska..., s. 310.
} 
W kwietniu 1916 r. „Jednota”, organ prasowy Słowackiej Ligi, reagował na artykuły czeskiej prasy o „,czechosłowackim narodzie”: „Nemôžeme byt' Čechoslovákmi ani po páde Rakúsko-Uhorska, ale ani teraz, kdekol’vek sa organizujú Češi a Slováci v záujme oslobodenia svojich krajín. Nemôžeme byt' len akýmsi príveskom Čechov... Československého národa niet. Sú dva národy český a slovenský" 90 .

1 maja 1918 r. zgromadzenie socjalistyczne w Liptowskim św. Mikołaju (Liptovský sv. Mikuláš) uchwaliło - na wniosek V. Šrobára — rezolucję, „v ktorej sa žiadalo samourčovacie právo pre uhorskú vetev československého kmeňa. [...] Slovenský týždenník vo svojej správe nahradil tento výraz termínom pre národ slovenský" "91.

Narodowej odrębności Słowaków, a nawet odrębnej słowackiej państwowości, domagał się - 19 października $1918 \mathrm{r}$. — w parlamencie węgierskim (węg. magyar országgyülés) jedyny słowacki poseł Dr. Ferdiš Juriga: „Právo si žiadame na prirodzenom a historickom základe, aby sme, ako to aj král' Karol chce, ako osobitný národ svoju vlastnú a osobitnú štátnu pospolitost' tvorili na území, na ktorom sme usídlení"92.

Uznania Słowaków jako odrębnego narodu domagał się wielokrotnie prezes Słowackiej Partii Ludowej, ksiądz Andrej Hlinka, argumentując tak prawem naturalnym, jak i wielokrotnymi obietnicami T.G. Masaryka, dotyczącymi tak federacji, jak i autonomii Słowacji.

$\mathrm{Na}$ hasła czechosłowakizmu reagowało - 23 października $1918 \mathrm{r}$. — czasopismo „Jednota”: „My odprvoti hájime stanovisko, že Slováci sú národ osobitný, že sme s bratmi Čechmi dvaja, a nie jeden. [...]. My Slováci sme Slováci, a nie Česi ani čechoslováci" ${ }^{93}$.

Jozef Hušek, delegat Słowackiej Ligi, napisał - po powrocie do USA z dziesięciotygodniowego pobytu w Czecho-Słowacji: „,ǐlo im [hlasistom - J.C.] o úplné zliatie sa slovenského národa s českým [...] Masarykova ideológia o národnej jednotnosti Slovákov a Čechov je prostému slovenskému človekovi úplne cudzia, (...lebo) Slováci nechcú takú demokratickú prácu, ktorá sa musí konat' pod ochranou českých bodákov. [...] A z našich len toho pripustili k zodpovednému miestu, ktorý zapísal dušu svoju čechoslovakizmu"94.

\footnotetext{
90 Ibidem, s. 279.

91 Ibidem, s. 283.

92 Ibidem, s. 287.

93 Ibidem.

94 Ibidem, s. $302-303$.
} 


\section{Zákon o zriadení župných a okresných úradov v Republike Československej (č. 126/1920 Zb.)}

Ustawa z 29 lutego 1920 r. o utworzeniu urzędów żupnych i powiatowych była jedną z pięciu ustaw konstytucyjnych, uchwalonych tego samego dnia, co ustawa zasadnicza Republiki Czechosłowackiej ${ }^{95}$. Cały obszar państwa dzieliła na 21 żup, z tym że na terytorium Słowacji likwidowała istniejące do rozpadu Węgier (16) żupy historyczne, wprowadzając 6 wielkich żup (słow. vel’župa), oznaczonych numerami od XV do XX. Były to następujące jednostki podziału administracyjno-terytorialnego: żupa XV (Bratysławska) z siedzibą w Bratysławie; żupa XVI (Nitrzańska) z siedzibą w Nitrze; żupa XVII (Poważsza) z siedzibą w Martinie; żupa XVIII (Pohrońska) z siedzibą w Zwoleniu; żupa XIX (Podtatrzańska) z siedzibą w Liptowskim Mikulaszu; i żupa XX (Koszycka) z siedzibą w Koszycach ${ }^{96}$. Z podziału na żupy ustawa wyłączała miasto stołeczne Pragę. W roku 1926 utworzono żupę obejmującą Ruś Podkarpacką, z siedzibą w Mukaczewie. Żupy składały się z powiatów (słow. okres).

Głównym celem ustawy była unifikacja administracji. W praktyce nie była to pełna unifikacja, gdyż na ziemiach czeskich postanowienia ustawy nie zostały zrealizowane. Ustawa żupna doprowadziła do upaństwowienia (etatyzacji) administracji publicznej, tj. do znacznego ograniczenia uprawnień pochodzących z wyboru organów samorządowych, oraz prawem rządu do mianowania 1/3 członków żupnych przedstawicielstw (župné zastupitel'stva) ${ }^{97}$.

Kilka rozwiązań ustawy żupnej żywo przypomina postanowienia polskiej ustawy z 23 marca 1933 r. o częściowej zmianie ustroju samorządu terytorialnego (Dz.U. R.P. Nr 35, poz. 294).

Podział ziem słowackich na 6 wielkich żup unicestwiał samorząd terytorialny Słowacji, jako odrębnej jednostki administracyjnej, przez co poddawał każdą z żup z osobna ściślejszej zależności od praskich organów centralnych. Ustawa żupna stanowiła więc istotny instrument etatyzacji i centralizacji administracji słowackich ziem.

E. Stodola i M. Hodža reprezentowali pogląd, że ustawa nr 126/20 Zb. wprowadza na Słowacji autonomię administracyjną, która — według E. Stodoly po decentralizacji praskich organów wykonawczych (etap drugi) doprowadzi Słowację do autonomii legislatywnej, sprawowanej przez słowacki sejm ${ }^{98}$.

${ }^{95}$ Obszerną i szczegółową analizę prawną ustawy przedstawił wybitny słowacki historyk prawa Ladislav Hubenák. Zob. Idem: Právne dejiny..., s. 154-161.

${ }^{96}$ Ibidem, s. 155; R. Letz: Slovenské dejiny..., s. 164.

${ }^{97}$ L. Hubenák: Právne dejiny..., s. 157; R. Letz: Slovenské dejiny..., s. 164.

${ }^{98}$ R. Letz: Slovenské dejiny..., s. 165. 
W kręgach władz centralnych i zwolenników idei czechosłowakizmu reprezentowano pogląd, że słowaccy autonomiści nie muszą walczyć o autonomię, gdyż — po wejściu w życie ustawy żupnej — już ją mają.

\section{Bibliografia}

Ajnenkiel A.: Plebiscyty w Polsce i w Europie po I wojnie światowej. W: Z perspektywy sześćdziesięciu lat. [Red. H. Janowska, M. Nowak-Kiełbikowa]. Warszawa 1982.

Brauneder W:: Österreichische Vefassungsgeschichte. Graphische Darstellungen F. Lachmayer. Wien 1989.

Beneš Edvard (1884-1948). In: Slovenský biografický slovník (od roku 833 do roku 1990). I. zväzok: $A-D$. Martin 1986.

Ciągwa J.: Dejiny štátu a práva na území Československa v období kapitalizmu 1848-1945. I. 1848-1918. Bratislava 1971. [Rec.]. „Czasopismo Prawno-Historyczne" 1973 , T. 25 , z. 1.

Ciąg wa J.: Mosný P.: „Podkarpatská Rus. Nerealizovaná autonómia”. Bratislava 2001. [Rec.]. „Czasopismo Prawno-Historyczne” 2003, T. 55, z. 1.

Ciąg wa J.: Alojz Miškovič obranca integrity Slovenska. W: Almanach Stowacy w Polsce VII. Almanach Slováci v Polsku VII. Kraków/Krakov 2000.

Ciągwa J.: Stowacka ideologia narodowa na przelomie: Ludovit Štúr (1815-1856). [Niepublikowana rozprawa doktorska napisana pod kierunkiem prof. dr. hab. Jana Baszkiewicza, Uniwersytet Śląski]. Katowice 1971.

Ciągwa J.: Dejiny štátu a práva na území Československa v období kapitalizmu 1848-1945. II. 1918-1945. Bratislava 1973. [Rec.]. „Czasopismo Prawno-Historyczne" 1975 , T. 27 , z. 1.

Ďurica M.S.: Dejiny Slovenska a Slovákov v časovej následnosti faktov dvoch tisícroči. Bratislava 2007.

Ďurica M.S.: Józef Tiso 1887-1947. Rys biograficzny. Tłum. x.L. Królikowski. Warszawa 2019.

Ďurica M.S.: Jozef Tiso 1887-1947. Životopisný profil. Bratislava 2006.

Dejiny Slovenska. V: (1918-1945). Vedecký red. S. Cambel. Bratislava 1985.

Dejiny štátu a práva na území Československa v období kapitalizmu 1848-1945. I: 1848-1918. Redakciu viedol L. Bianchi, vedecký redaktor L. Hubenák. Bratislava 1971.

Dejiny štátu a práva na území Československa v období kapitalizmu 1848-1945. II: 1918-1945. Bratislava 1973.

Felczak W., Wasilewski T.: Historia Jugosławii. Wrocław-Warszawa-KrakówGdańsk—Łódź 1985.

Grodziski S.: „Habsburgergesetz” - austriacka ustawa konstytucyjna z 3 kwietnia 1919 roku. W: Państwo, prawo, społeczeństwo w dziejach Europy Środkowej. Księga jubileuszowa dedykowana Profesorowi Józefowi Ciagwie w siedemdziesięciole- 
cie urodzin. Komitet redakcyjny A. Lityński, M. Mikołajczyk, T. Adamczyk, A. Drogoń, W. Organiściak. Katowice-Kraków 2009.

Gruchała J.: Tomasz Masaryk. Wrocław 1996.

Hajko J.: Nezrelá republika. Slovensko v rokoch 1939-1945. Bratislava 2009.

Heck R., Orzechowski M.: Historia Czechosłowacji. Wrocław 1969.

Hubenák L.: Právne dejiny Slovenska do roku 1945. II. diel. Banská Bystrica [b.r.w.]. Kautský E.K.: Kauza Šefánik. Legendy, fakty a otázniky okolo vzniku Česko-Slovenskej republiky. Bratislava 2007.

Kirschbaum S.J.: A History of Slovakia. The Struggle for Survival. New York, NY 1995.

Klimko J.: Slovenská republika rád. (Pokus o socialistickú štátnost'). Bratislava 1979. Klimko J.: Vývoj územia Slovenska a utváranie jeho hraníc. Bratislava 1980.

Kościelak L.: Historia Stowacji. Wrocław 2010.

Latinské právnické výrazy a výroky. Vybral, preložil a výkladom doplnil K. Rebro. Bratislava 1984.

Letz R.: Čechoslovakizmus. In: Lexikón slovenských dejín. Red. L. Adamčíková. Bratislava 1997.

Letz R.: Slovenské dejiny. IV: 1914-1938. Bratislava 2010.

Litew ski W.: Stownik encyklopedyczny prawa rzymskiego. Kraków 1998.

Lexikón slovenských dejín. Red. L. Ada mčíková. Bratislava 1997.

Lexikón svetových dejín. Red. Y. Kaštanová. Bratislava 1997.

Mosný P.: Podkarpatská Rus. Nerealizovaná autonómia. Bratislava 2001.

Malá encyklopédia Slovenska. Súhrn poznatkov o minulosti a pritomnosti Slovenska $A-Z ̌$. Vedecký red. V. Hajko. Bratislava 1987.

Masaryk Tomáš Garrigue (1850-1937). In: Slovenský biografický slovnik (od roku 833 do roku 1990). IV. zväzok: $M-Q$. Martin 1990.

Mosný P.: Podkarpatská Rus. Nerealizovaná autonómia. Bratislava 2001.

Pajewski J.: Historia powszechna 1871-1918. Warszawa 2004.

Pajewski J.: Pierwsza wojna światowa 1914-1918. Warszawa 1991.

Prawo rzymskie. Stownik encyklopedyczny. Red. W. Wołodkiewicz. Warszawa 1986.

Rogul'ová J.: Vznik Československa; Československo v rokoch 1918-1938; Adminstratívne členenie Slovenska v rokoch 1918-1938. In: Ottov historický atlas Slovensko. Zostavil P. K r š á k. Praha 2009.

Rušin V.: Astronóm Milan Rastislav Štefánik. Bratislava 2009.

Skaloš M.: Proces utvárania Slovenských hranic ako štátnych hraníc ČSR (historické a právne aspekty). „Z Dziejów Prawa” 2012, T. 5 (13).

Sondel J.: Słownik łacińsko-polski dla prawników i historyków. Kraków 2005.

Švorc P.: Rozbijali monarchiu. (Populárny slovník osobností česko-slovenského odboja 1914-1918). Košice 1992.

Švecová A., Gábriš T.: Dejiny štátu, správy a súdnictva na Slovensku. Plzeň 2009.

Slovensko. 1: Dejiny. Zostavovatel' a vedecký redaktor J. Tibenský. Bratislava 1971.

Štefánik Milan Rastislav (1880-1919). In: Slovenský biografický slovník (od roku 833 do roku 1990). V. zväzok: $R-\check{S}$. Martin 1992.

Tibenský J. [a kol.]: Slovensko. 1: Dejiny. Zostavovatel' a vedecký redaktor J. Tibenský. Bratislava 1971.

Vaněček V.: Dějiny státu a práva v Československu do roku 1945. Praha 1976. 
Vojáček L., Schelle K., Knoll V.: České právní dějiny. Plzeň 2010.

Wereszycki H.: Pod bertem Habsburgów. Zagadnienia narodowościowe. Kraków 1975.

Józef Ciągwa

\section{Der Erste Weltkrieg und die Gründung der Tschechoslowakischen (Tschechisch-Slowakischen) Republik 1914-1920 (Ausgewählte Themen)}

Schlüsselwörter: Erste Tschechisch-Slowakische Republik, Prager Zentralismus, Idee des Tschechoslowakismus, Autonomie der Slowakei

Zusammenfassung: Die erste Tschechisch-Slowakische Republik wurde im Herbst 1918 gegründet. Diesem Datum gingen vor einigen Jahren interne und vor allem externe Maßnahmen (von den USA, Frankreich, der Schweiz, Russland) voraus, die die Schaffung des ersten gemeinsamen Staates der Tschechen und Slowaken erleichterten und beschleunigten. Dazu gehörten: Gründung des Tschechisch-Slowakischen Nationalrats in Paris; Abkommen zwischen tschechischen und slowakischen Organisationen von 1915 (das Cleveland-Abkommen) und Abkommen von 1918 (das Pittsburgh-Abkommen); Schaffung tschechisch-slowakischer Legionen in Italien, Frankreich und Russland; millionste Geldsammlung unter slowakischen Auswanderern für den Aufbau eines gemeinsamen Staates; Anerkennung des Tschechoslowakischen Nationalrats als Übergangsregierung der Tschechisch-Slowakischen Republik durch die USA, Frankreich, Italien, England und Russland.

Von Anfang an war das Ungleichgewicht zwischen der rechtlichen und tatsächlichen Stellung der Tschechen und Slowaken im politischen System des neuen Staates sichtbar. Ein klassisches Beispiel für dieses Ungleichgewicht waren die Gründung der Ersten Republik durch den Beschluss des Tschechischen Nationalkomitees vom 28. Oktober 1918 in Prag, ohne auf die Zustimmung des Slowakischen Nationalrates in Turč. Sv. Martin zu warten, die in der Erklärung vom 30. Oktober 1918 zum Ausdruck kam und kurz darauf die Auflösung des Rates, obwohl seine Erklärung besagte, dass der Rat die einzige Vertretung des slowakischen Volkes sei.

Die konsequente Fortsetzung der zentralistischen Politik Prags war die Idee des Tschechoslowakismus, die in der Verfassung vom 29. Februar 1920 und in anderen Verfassungsgesetzen (auch vom 29. Februar 1920) festgeschrieben wurde und die annimmt, dass es keine eigene slowakische Nation gibt und die Slowaken nur ein Zweig der tschechischen Nation sind. Diese Stellungnahme von T.G. Masaryk, E. Beneš, Hlasisten und Prudisten führten zu einem 20-jährigen Streit zwischen Zentralisten und slowakischen Autonomisten, die von dem Vorsitzenden der Slowakischen Volkspartei, Priester Andrej Hlinka vertreten waren.

Das Verfassungsgesetz über die Errichtung von Salinen- und Kreisämtern vom 29. Februar 1920 führte zur Etatisierung der öffentlichen Verwaltung, d.h. zu einer erheblichen Einschränkung der Selbstverwaltung. In den Kreisen der Zentralbehörden und Befürworter der Idee des Tschechoslowakismus wurde die Ansicht vertreten, dass slowakische Autonomisten um die Autonomie nicht kämpfen müssen, weil diese sie bereits nach dem Inkrafttreten des Salinengesetzes haben. 
Józef Ciągwa

\section{The First World War and the establishment of the Czechoslovak Republic (Czech and Slovak Republic) 1914-1920 (Selected issues)}

Keywords: First Czech and Slovak Republic, Prague centralism, the idea of Czechoslovakism, Slovakia's autonomy

Summary: The First Czech and Slovak Republic was established in the autumn of 1918. This date was preceded by several years of internal and, above all, external (USA, France, Switzerland, Russia) actions which facilitated and accelerated the creation of the first common state of Czechs and Slovaks. These facts included the establishment of the Czech-Slovak National Council in Paris, the 1915 agreements between the Czech and Slovak organizations (the Cleveland Agreement) and the 1918 agreement (the Pittsburgh Agreement); the creation of Czech-Slovak legions in Italy, France and Russia; the million-dollar fundraising among Slovak emigrants to build a common state; the recognition of the Czechoslovak National Council as the interim government of the Czech and Slovak Republic by the USA, France, Italy, England and Russia.

From the very beginning, a state of imbalance between the legal and factual position of Czechs and Slovaks in the new state's system was evident. A classic example of this imbalance was the establishment of the First Republic by a decision of the Czech National Committee in Prague on 28 October 1918, without waiting for the approval of the Slovak National Council in Turčiansky Svätý Martin, expressed in the declaration of 30 October 1918, and soon afterwards the disestablishment of the Council, despite the fact that its declaration stated that the Council was the only representation of the Slovak nation.

A consistent continuation of the centralist policy of Prague was the idea of Czechoslovakism, enshrined in the Constitution of 29 February 1920 and other constitutional laws (also of 29 February 1920), assuming that there is no separate Slovak nation and that Slovaks are only a branch of the Czech nation. This position of T.G. Masaryk, E. Beneš, Hlasists and Prudists led to a 20 -year-long dispute between centralists and Slovak autonomists, represented by the chairman of the Slovak People's Party, priest Andrej Hlinka.

The Constitutional Act on the establishment of county and district offices of 29 February 1920 led to the etatization of public administration, i.e. to a significant reduction in self-government. In the circles of central authorities and supporters of the idea of Czechoslovakism, there was a view that Slovak autonomists did not have to fight for autonomy, because after the entry into force of the County Act they already had it. 